\title{
A Study of Adoption of Milking and Healthcare Practices of Dairy Animals under Co-Operative Network of Rajkot Milk Marketing Union of Saurashtra
}

\author{
Jaysukh B. Kathiriya ${ }^{1 *}$, Samiullakhan H. Sindhi ${ }^{1}$ and Hetal A. Manwar ${ }^{2}$ \\ ${ }^{1}$ Department of Veterinary Public Health \& Epidemiology, College of Veterinary Science \& \\ Animal Husbandry, Junagadh Agricultural university, Junagadh, Gujarat, India \\ ${ }^{2}$ Krishi Vigyan Kendra, Main Dry Farming Research Station, Junagadh Agricultural University, \\ Targhadia, Rajkot, Gujarat, India \\ *Corresponding author
}

\begin{tabular}{|c|c|}
\hline & A B S T R A C T \\
\hline $\begin{array}{l}\text { Healthcare } \\
\text { practices, } \\
\text { Dairy animals, } \\
\text { Milking } \\
\text { adaptation }\end{array}$ & \multirow{3}{*}{$\begin{array}{l}\text { A bench mark survey was undertaken to find out the dairy animal management } \\
\text { practices followed by the member farmers of dairy co-operative society in } \\
\text { randomly selected three talukas of Rajkot district in Saurashtra region of Gujarat } \\
\text { state. In each taluka five villages and in each village ten respondents were } \\
\text { selected. It was observed that all the respondents milked their animals twice in a } \\
\text { day by using wet knuckling method }(98 \%) \text { of milking - Majority of the milked } \\
\text { produced generally goes to dairy co - operative society except the amount, which } \\
\text { routinely used for family need. All the respondents adopted practices to vaccinate } \\
\text { their animals against Foot and Mouth Disease (FMD) and Haemorrhagic } \\
\text { Septicemia (HS). There is facility of integrated veterinary treatment camp } \\
\text { services, which provide vaccination of animals and other veterinary needs. }\end{array}$} \\
\hline Article Info & \\
\hline $\begin{array}{l}\text { Accepted: } \\
20 \text { March } 2017 \\
\text { Available Online: } \\
10 \text { April } 2017\end{array}$ & \\
\hline
\end{tabular}

\section{Introduction}

The animal husbandry sector employ about 8 per cent of India's total labour force, contributes about 6 per cent of total GDP and 26 per cent of the value of India's total agricultural output (Biswas, 2000). India has made a remarkable progress in the last three decades and has emerged as leading milk producer in the world. It is producing about 91 million tones (FAO, 2005). Gujarat has achieved leading position in milk production and marketing through development of wide of wide network of co-operative system. Gujarat co-operative Milk Marketing federation, presently comprises of 12 milk unions. Among them Rajkot district cooperative milk union was taken for the present study to collect information regarding dairy animal managemental practices in rural areas.

\section{Materials and Methods}

A bench mark survey was conducted (July2008 to September 2008) to collect the information of dairy animal mangemental practices adopted by the farmers of Rajkot district of Gujarat state. Three talukas were randomly selected viz., Padadhari, Wankaner and Rajkot. Five Villages were selected from 
each taluka viz., Metoda, Sarapdad, Suvag, Amreli-nana and Kerala from Padadhari, Kothi, Samadhiyala, Jalida, Mesariya and Lunsar from Vankaner and Magharvada, Deroi, Bedla, Khorana and Ranpur from Rajkot. In each village ten farmers who reared dairy animal/s (Peak milk yield $10 \mathrm{~kg}$ or more per day) were selected by using of multi-stage random sampling technique (Snedecor and Cochran, 1967). The desired information was gathered by using a specially developed questionnaire that contains various parameters of milking and health care practices of dairy animals. The qualitative data, which generated in the study were quantified and tabulated. Finally the data were classified according to land holding and literacy of the farmers to draw meaningful inferences.

\section{Results and Discussion}

\section{Particulars of household and his farm}

The information about socio-economic aspects of respondents revealed that 15 per cent farmers educated up to primary, matric and above matric level respectively. On the other hand 38, 33 and 29 per cent farmers have small ( $>5$ acres), medium (5-10 acres) and large (>10 acres) land holding, respectively.

\section{Milking Practices}

It was revealed that all respondents (100\%) followed two times milking by cleaning teat and udder via splashing water before milking. Similarly, Hazarika and Anand (1984) reported that majority $(93.33 \%)$ of farmers followed hygienic steps before onset of milking. It was found that 97 per cent farmers habituated to wet hand knuckling method of milking, while only 3 per cent farmers practiced full hand milking method with dry hand full hand milking method with dry hand. Similar trend was found by Chowdhry et al., (2008). The literacy of farmers had no significant association with method and habit of milking. The data revealed that 88.35 and 11.65 percent farmers adopted practices to dry-off their cows in less than two months and two months or more respectively, while $8.00,60.00$ and 32.00 percent buffalos dried off for less than 2, 2 to 3 and more than three months respectively.

Table.1 The problems faced by the respondents with percentage

\begin{tabular}{|l|l|l|l|}
$\begin{array}{l}\text { Sr. } \\
\text { No. }\end{array}$ & Problems faced by the respondents & Number & Percentage \\
\hline $\begin{array}{l}\text { A. Socio Economic profile } \\
\text { Age }\end{array}$ & \multicolumn{2}{|l|}{} \\
\hline 1. & Upto 35 years & 24 & 36.00 \\
\hline 2. & 36 to 50 years & 33 & 50.00 \\
\hline 3. & More than 50 years & 9 & 14.00 \\
\hline Educational status of the participants & 10 & 15.00 \\
\hline 1. & Illiterate & 25 & 37.00 \\
\hline 2. & Primary level & 28 & 42.00 \\
\hline 3. & S.S.C. / H.S.C. level & 4 & 6.00 \\
\hline 4. & Graduate and above & \multicolumn{2}{l|}{} \\
\hline Area of farm land (Hectares) & 9 & 14.00 \\
\hline 1. & Less than 1 ha. & 19 & 29.00 \\
\hline 2. & 1 to 2 ha. & 17 & 25.00 \\
\hline 3. & 2 to 4 ha. & 21 & 32.00 \\
\hline 4. & More than 4 ha. & \multicolumn{2}{l|}{} \\
\hline
\end{tabular}


The result concluded that majority of cows dry off for less than two months where as buffalos dry off for two to three months. All respondents dispose their major portion of milk through village dairy co-operative society.

\section{Healthcare practices}

All the respondents practiced regular vaccination of their animals against FMD and HS. Vaccination against Black Quarter (BQ) was not practiced regularly but in suspected area mass vaccination was practiced both in case of cattle and buffaloes. It revealed that 15 and 39 per cent farmer practice deworming for their mulch animal and at regular and occasional basis. In calf 32 and 38 per cent farmers practiced deworming on regular and occasional basis. However, 30 per cent farmers never practiced deworming. Most of farmers did not followed the practiced of controlling ectoparasites. Some farmers adopted traditional practices like smoke of neem leaves to prevent the flies and mosquitoes and salt spray to control leeches. These findings are in agreement with Verma (1989). Majority of farmers did not use any disinfectants and insecticides. It was found that 82 per cent farmers have clean shed while 18 per cent farmers did not give more attention towards sanitary condition of shed.
Housewife played major role in heeding practices of animals, such as milking, feeding and cleaning of manger and shed. Majority of farmers $(75 \%)$ treated their sick animals by Govt. Veterinarian whereas 25 per cent were in favour of either livestock supervisor or local quacks. Generally, farmers preferred veterinary services from Govt. Veterinarian because unavailability of regular veterinary services from dairy veterinarian.

\section{References}

Biswas, M. (2000). Poultry Advisor, 33(3): 719.

Chowdhry, N.R., Patel, J.B. and Mukesh Bhkat (2008). Indian J. Anim. Res., 42(2): 153-154.

F.A.O. (2005). Food and Agricultural Organization Production year Book. Food and Agricultural Organization of United Nations, Rome.

Hazarika, P. and Anand, A. (1984). Dairy Guide. 6(5): 46-53.

Snedecor, G.W. and Cochran, W.G. (1967). Statistical Methods for Agricultural Workers, $8^{\text {th }}$ Edn. Oxford \& $10 \mathrm{H}$ pub. Co., New Delhi.

Verma, A.K. (1989). Ph.D. Thesis. CCS Haryana Agric. University, Hisar.

\section{How to cite this article:}

Jaysukh B. Kathiriya, Samiullakhan H. Sindhi, Hetal A. Manwar. 2017. A Study of Adoption of Milking and Healthcare Practices of Dairy Animals under Co-Operative Network of Rajkot Milk Marketing Union of Saurashtra. Int.J.Curr.Microbiol.App.Sci. 6(4): 2347-2349. doi: https://doi.org/10.20546/ijcmas.2017.604.273 